\title{
Assessment of Recent Lateral Channel Migration characteristics of the Lower Section of River Digil, Mubi North, Adamawa State, Nigeria
}

\author{
Ezekiel Yonnana \\ Department of geography Adamawa State University Mubi, Adamawa State Nigeria \\ *Contact: ezekiel97@ adsu.edu.ng. +234(0)8036627553
}

DOI: 10.29322/IJSRP.11.08.2021.p11637

http://dx.doi.org/10.29322/IJSRP.11.08.2021.p11637

\begin{abstract}
The analyses of migration patterns and rates over time the mapping of Channel Migration Zones (CMZ) and are vital geomorphologic activities for policy making and management of riparian land uses in a river valley system. In this study, an assessment of recent (2006 - 2021) Lateral Channel Migration of a segment of River Digil was conducted. The study focused on assessing the nature and magnitudes of lateral channel migration of the Digil River in the recent times, mapping out the CMZ and ascertaining the present and future implications of the channel migration process on the riparian land uses. The methodology employed the integrated approach of field studies, Remote Sensing and Geographic Information System (GIS) Analyses. Results showed a of 3.52m channel migration per year from 2006 to 2012 and $2.32 \mathrm{~m}$ per year from 2012 to 2019 . Though the rates were seemingly low were found threatening to riparian agricultural land uses and landed property within the migration corridor. The delineated CMZ covered a total area of $7.2 \mathrm{~km} 2$ and occupied mostly by farmland and few residential areas. Buffering and policies restricting developmental projects within the CMZ were recommended as measures for conservation and management.
\end{abstract}

Keywords: Lateral Channel Migration; River Digil; Stream flow; Channel Migration Zone; Riparian Land Uses

\section{Introduction}

River channels are fluvial landforms that are subject to geometric transformations owing to changes the stream hydraulic regime. Among the forms of geometric transformation that occur over alluvial channels is Channel Migration. This is a process by which stream channels are subjected to adjustments resulting to modification of their floodplains over time (Wolman and Leopold, 1957; Legg \& Olson, 2014; Yonnana et al., 2020). Channel migration can occur in the form of Lateral Migration; a gradual process leading to change in the channel course as the stream flow results to erosion of the concave bank and sediment deposition on the convex bank - (Leopold and Wolman, 1960; Knighton, 1998; Yonnana et al., 2020), or a sudden transferal of the channel course to a new location (commonly referred to as avulsion), which may occur during an occasional flood (Leopold et al., 1995; Knighton, 1998; Larsen, 2007, King County, 2018). However, the current study on Digil River segment is confined mainly to lateral channel migration as no evidences of avulsion noticed based on pass and recent observations.

Lateral channel migration strongly depends on the flow behavior of the stream and the susceptibility or resistance of the channel banks to erosion by stream flow (Nanson and Croke, 1992). It is a characteristic process of alluvial channels that is in most cases influenced by composition of channel bank material, channel geometry, stream discharge and nature of riparian vegetation (Janes et al 2017). River banks migrate rapidly where the stream energy and sediment loads are relatively high and the erosion resistance of the channel perimeter is low (Boyd et al., 2010).

The area within which a river channel is likely to move due to erosion over a period of time is referred to as channel migration zone CMZ (GeoEngineers, 2013). Since the zone is potentially susceptible to erosion, is regarded as a hazardous area for development. Therefore, Human encroachment into channel migration prone zones for various resources exploitation and land utilization often results to substantial economic effects that are connected to loss of property. Besides, efforts to limit channel migration and protect development are not only expensive, but can adversely impact fluvial ecosystems, worsen downstream flooding, and induce damage to adjacent or a cross-channel property (Legg and Olson 2014).

Channel Migration Zone (CMZ) delineation is a very important procedure precedes policy making and proper management of riparian lands liable to adverse threats of lateral channel migration (Rapp and Abbe, 2003). They further clarified that, delineation of Channel Migration Zone helps greatly in predicting areas at risk of channel erosion by fluvial processes. It also helps in guiding human encroachment into the area for infrastructural development purposes there by reducing hazardous risk on human communities along 
ISSN 2250-3153

river systems. Limiting development within CMZs also reduces the costs of repairing or replacing infrastructure and major civil works that might otherwise be threatened or damage by channel migration. Besides, the delineation of CMZs allows landowners, planners and other entities to determine if they have facilities that could be affected by erosion, plan for future development that safeguards human welfare and critical habitat, and identify sites that may need erosion protection or habitat restoration opportunities (GeoEngineers, 2013).

With the recent urbanization developments in Mubi metropolis (Ajala and Tammi 2012), property ownership and infrastructural developments are fast advancing into the Digil River valley area without concerns or attention to the possible effects of channel migration. Therefore, understanding the temporal nature and magnitude of channel migration and the demarcation of the Channel Migration Zone (CMZ) over the study river section are very key to proper conservation and management of riparian lands for socioeconomic, environmental, and public safety benefits. It is against this backdrop that the current study examines the Recent conditions of Lateral Channel Migration of the lower reaches of the Digil River and mapping of its channel migration Zone for planning, conservation and management policy

\section{Materials and Methods \\ Description of the study area}

River Digil is a major tributary of the Yedzeram consequent stream in Mubi, Adamawa State, Nigeria. It originates from the DirbishiMaduguva hills of the Mandara Mountains (Federal Surveys Nigeria, 1970) as shown in Figure 1. Being the only perennial stream in the Upper Yedzeram River Basin, the Digil River is of great relevance in terms of water supply for municipal uses in Mubi metropolis as well as for domestic uses in many rural settlements. It also supports the socioeconomic livelihood of a large human population in terms of irrigation agriculture, animal production fishing and supply of gravel for construction works.

The hydrological functionality of the river is strongly connected to the climatic regime, geology, relief and soils of the area as described by applicable authors in Adebayo (2004). The rainfall regime is characterized by distinct wet and dry seasons that yield mean annuals of about $900 \mathrm{~mm}$ to $1050 \mathrm{~mm}$ or more. A significant proportion of the rain water ends up in the stream channels as stream flow owing to the nature of the area's geology (impermeable Basement complex rocks), rugged dissected relief (mountains, hills and undulating high plains) and shallow embryonic soils (Lithosols and Luvisols).

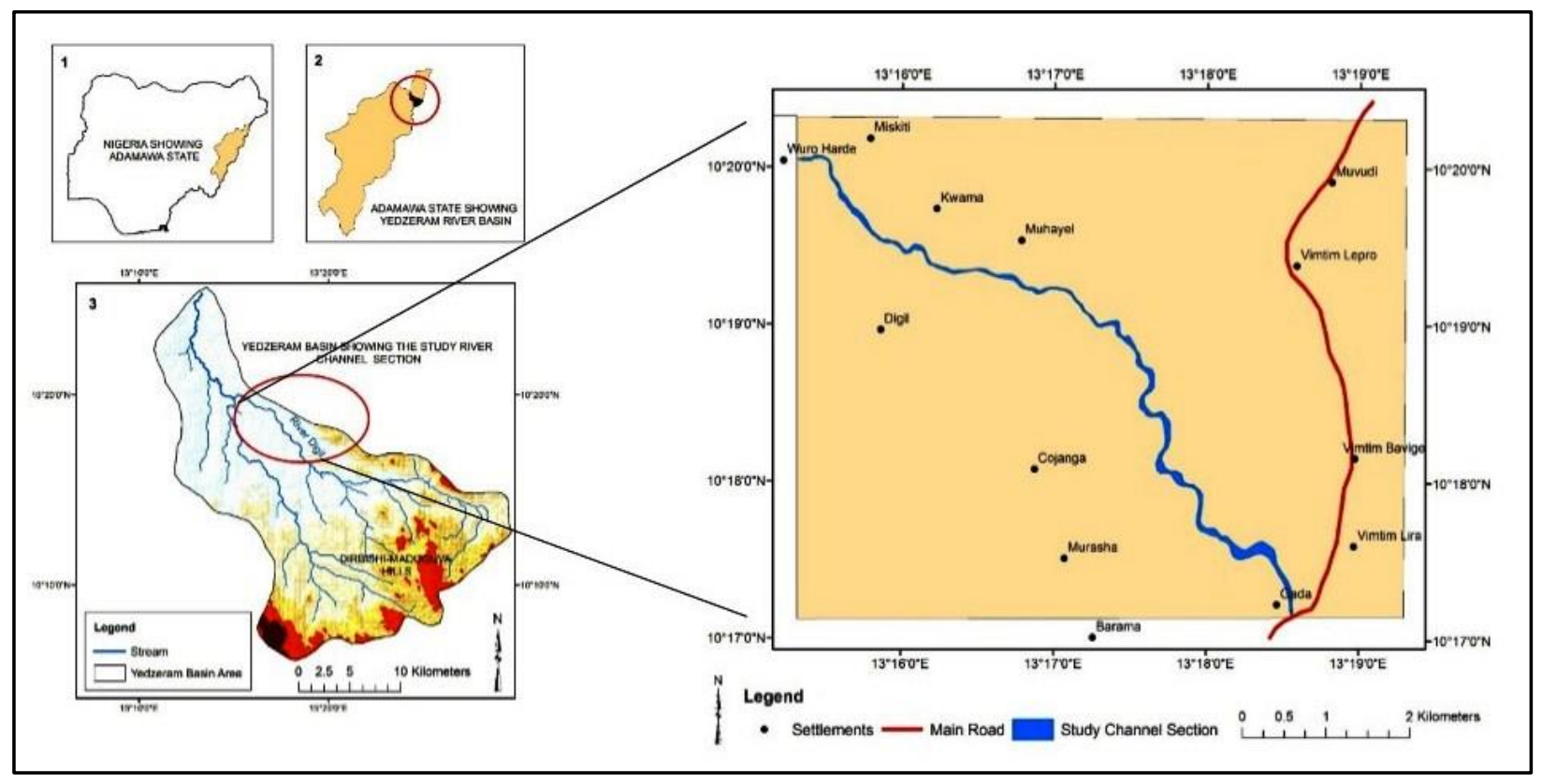

Figure 1: The study river system channel section

The study channel section of the Digil River is located between latitudes $10^{\circ} 17^{\prime} 00^{\prime \prime} \mathrm{N}$ and $10^{\circ} 20^{\prime} 00^{\prime \prime} \mathrm{N}$ of the Equator and between longitudes $13^{\circ} 15^{\prime} 00^{\prime \prime} \mathrm{E}$ and $13^{\circ} 19^{\prime} 00^{\prime \prime} \mathrm{E}$ of the Greenwich Meridian (Figure 1). It extends from Gada to the Wuro Harde covering a total length of $10.3 \mathrm{~km}$.

\section{Assessment of Channel Migration Pattern and Rates}

2006, 2012 and 2019 Google Earth Images of the study section of River digil and its surrounding riparian area were obtained from www.google.earth.com and processed in ArcGIS 10.3 software. The channel bank lines and area polygons were digitized from each 
image. The centerlines and thw migration polygons were then generated using the procedures described by Alcantara (2014), Giardino and Rowly (2016), Das and Pal, (2016) and Yonnana et al., (2020). Areas and perimeters of the migration polygons were obtained from their attribute tables and copied onto the workspace of Microsoft Excel for the determination of Total Migration (Mn) and Yearly rate of Migration (Ry) using the following formulae as suggested Giardino and Rowley (2016);

$$
\begin{aligned}
& M n=\frac{A}{\frac{1}{2} P} \\
& R y=\frac{M n}{N}
\end{aligned}
$$

Where $\boldsymbol{M n}$ is total channel migration, $\boldsymbol{R} \boldsymbol{y}$ is yearly rate of migration, $\boldsymbol{A}$ is area of migration polygon, $\boldsymbol{P}$ is perimeter of migration polygon and $N$ is number of years in the study period (time interval).

\section{Channel Migration Zone Mapping}

The delineation of Channel Migration Zone (CMZ) for the study river section involved the combination of field survey and Geographic Information System approach. In the field survey routine, previous channel banks positions and extents as well as potential channel erosion extents were identified by field observation and confirmations from respondents that were fully in picture of the channel migration behavior since the 1970s. Germin eTrex Global Positioning System (GPS) was used for obtaining the demarcation coordinates of the identified historic and potential channel landmarks/extents. The data tabulated in text tab delimited format in Microsoft Excel software then exported to ArcGIS 10.3 environment as a point shape file for the CMZ delineation procedure. The delineation activity was completed by conducting a polygon digitization adjoining the landmark/extent points. The areal coverage of the delineated CMZ was then obtained using the Calculate Geometry Command of the CMZ shape file.

\section{Results and Discussion}

\section{Nature and temporal magnitude of channel migration}

The channel migration patterns from 2006 to 2012 and from 2012 to 2019 are presented by figure 3 . The patterns showed more lateral migration effect between 2006 and 2012 than between 2012 and 2019 possibly owing to greater rainfall events and fluvial activity. The results further revealed that from 2006 to 2012, the channel section migrated over a total distance of $21.10 \mathrm{~m}$ at a rate of $3.52 \mathrm{~m}$ per year, while a much lower total migration of magnitude of $16.23 \mathrm{~m}$ at a rate $2.32 \mathrm{~m}$ per year was obtained for the 2012 to 2019 period. This clearly indicates that going by recent trends (from 2006 to 2019), the lower section of the Digil River channel has been migrating at an average rate of $2.9 \mathrm{~m}$ per year, thus gradually infringing on the land uses within the possible zone of migration.

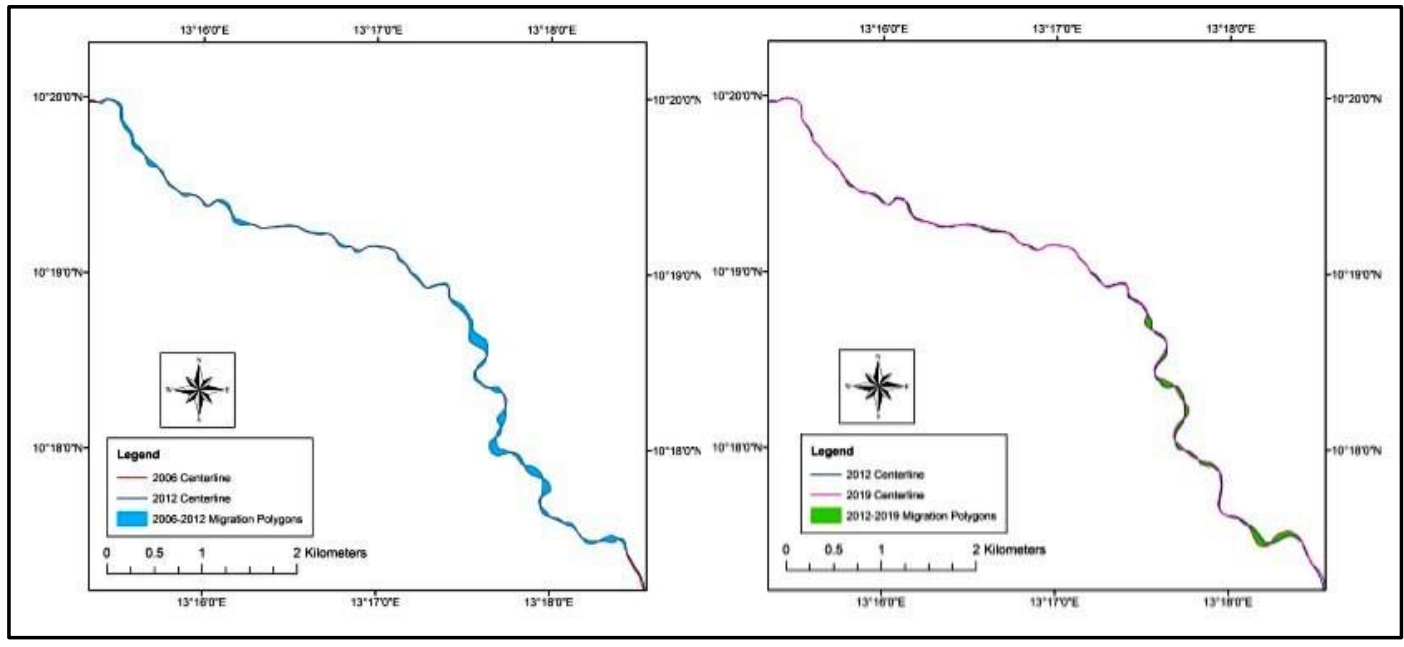

Figure 3: Channel Migration Patterns from 2006 through 2012 to 2019

However, the channel migration effect was more pronounced in the upstream part of the study channel section (from A to B) than the downstream as shown in Figure 4. It was found from field observation that the eminent meandering and lateral migration effect in this sub-section is tied to the Mubi water treatment plant constructed at Gada (A). At point A, a barrage was constructed across the river channel to trap and divert water into storage chambers in the treatment plant (plates 1 and 2). The barrage retards the normal stream flow behavior in the immediate $4.1 \mathrm{~km}$ downstream sub-section (from A to B), thus intensifying the meandering (S.I =1.3) and lateral 
ISSN 2250-3153

migration states of the sub-section, most especially during the periods of high stream discharges. The results further showed that meandering state ( $\mathrm{S} . \mathrm{I}=1.1$ ) of the remaining downstream sub-section (from B to the end point of the study section) becomes minimal as the channel sub-section regains its normal flow behavior from the barrage disturbance thus having minimal effect of lateral migration.

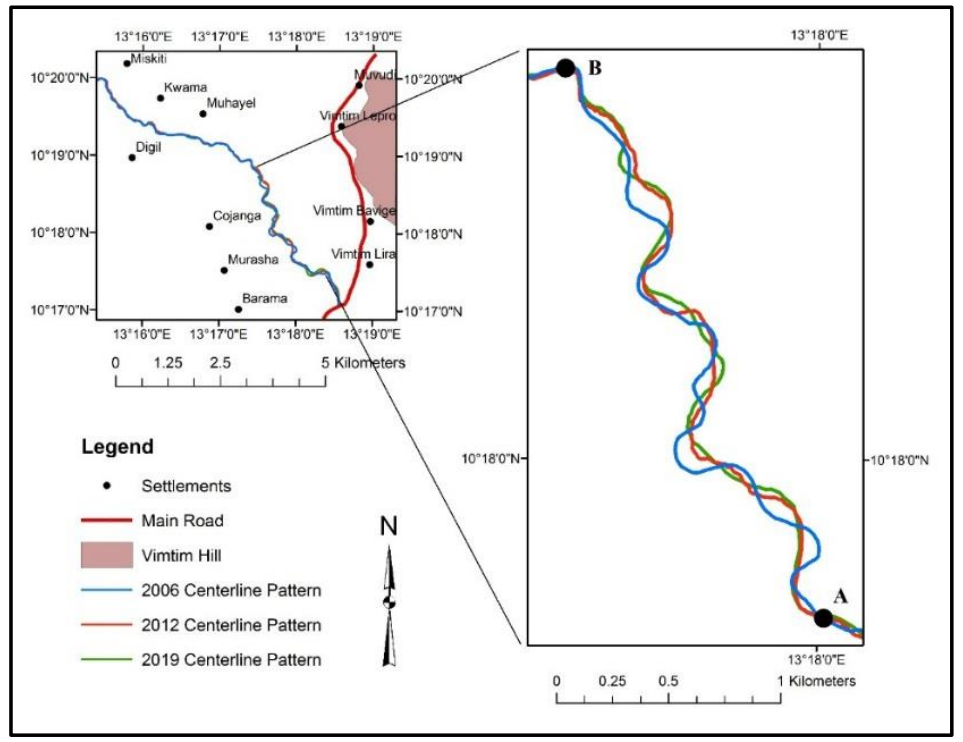

Figure 4: Trends of channel migration along the channel planform from 2006 to 2019

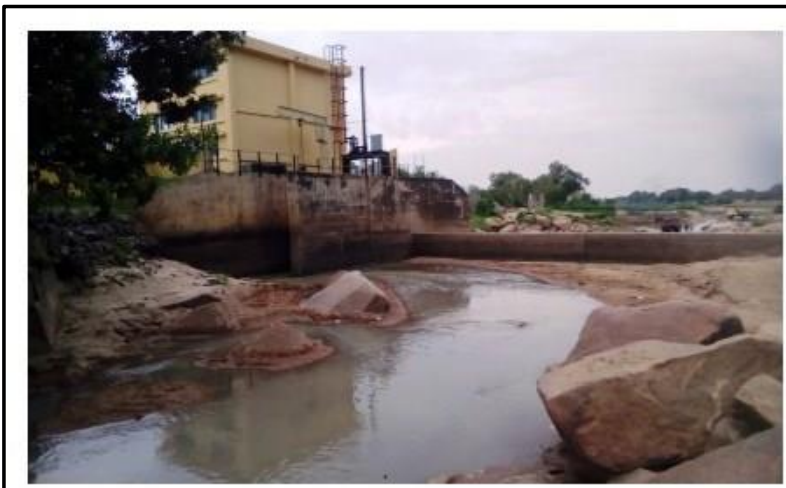

Plate 1

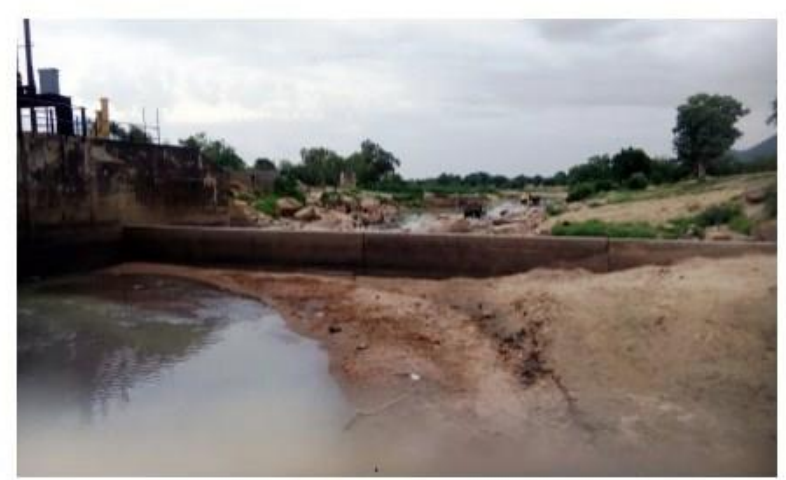

Plate 2

Plates 1 and 2: The barrage at Gada water treatment plant

On a general note, the channel lateral migration characteristic of the Digil River section (2.3m per year) was found to be averagely (about 50\%) low compared to the average rate observed over the nearest Yedzeram Channel (4.7m per year) by Yonnana et al 2020. This $50 \%$ variation in channel migration behavior is strongly tied to differences in channel geometry, flow behavior and level of anthropogenic disturbances between the two river channels.

\section{Delineated Channel Migration Zone}

Results showed that the demarcated Channel Migration Zone (CMZ) for the study river section covered an area of $7.57 \mathrm{~km}^{2}$ with an average width of $932.18 \mathrm{~m}$ (Figure 5). The CMZ portrayed an irregular and elongated shape which conformed greatly to the river valley relief, loose alluvial soils and fluvial behavior marked by intermittent episodic flash flood events during the rainy seasons. It was also observed that the lateral migration effect of the channel poses erosion threats to predominantly farmlands and few residential land uses which make up the entire CMZ. Channel banks failure and retreat were very rampant at many outside points of the river meanders (Plates 3 and 4). The existence of numerous plot beacons and signs of bricks wall construction within the CMZ were indications of land property ownership and encroachment by people with prospects of future infrastructural developments (Plate 5). This encroachment into the CMZ was more eminent in the last few years following the Boko Haram insurgents' attacks on humans and the destruction of many rural settlements in the northern Adamawa State resulting to the forceful migration of people into Mubi metropolis for settlement. 


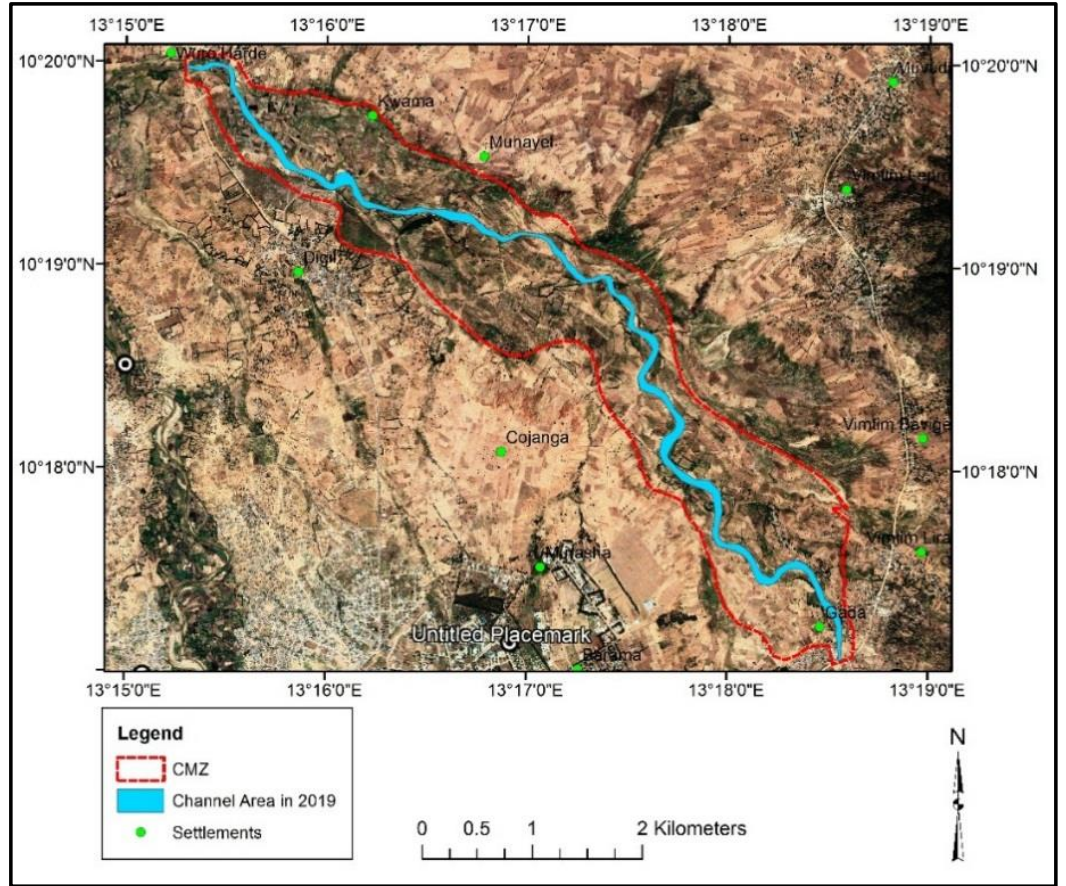

Figure 5: The demarcated Channel Migration Zone for the study river section
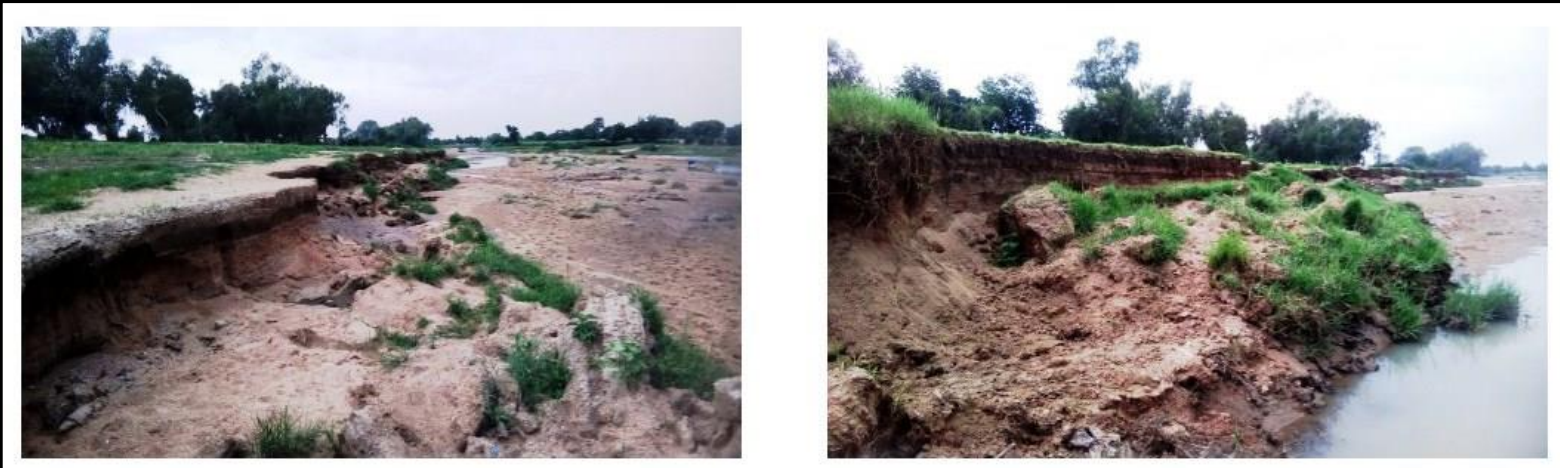

Plates 3 and 4: Eminences of channel banks failure at concave (outside) banks

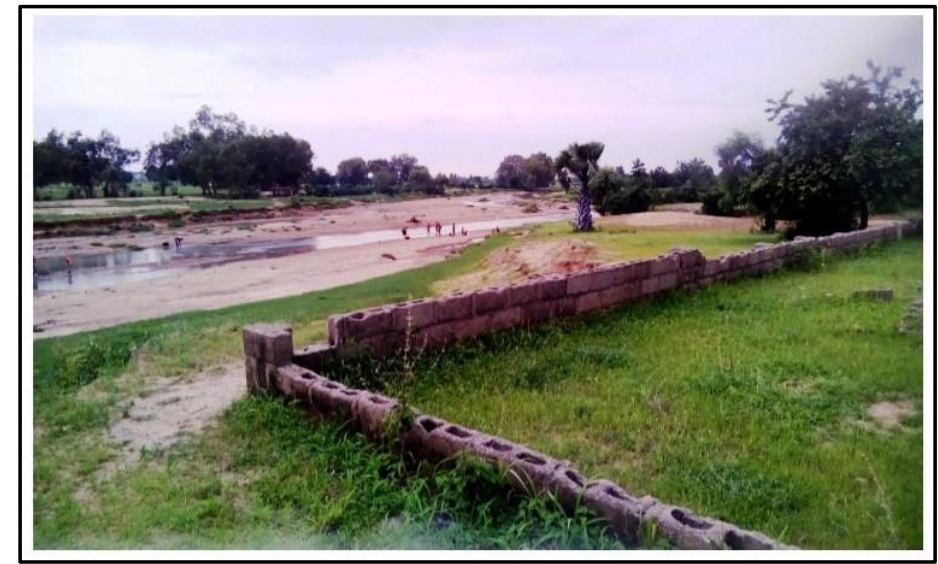

Plate 5: Bricks wall construction within the CMZ

\section{Conclusion}


Even though the current study was focused on recent and short term lateral channel migration over the lower section of the Digil River, the results serve as key pointers to past channel migration processes of the river. This notion is based on the fundamental concept of uniformitarianism which states that the same physical processes that the same physical processes that operate today, operated in the geologic past although not necessarily with the same magnitude and intensity. Simply interpreted as 'the present is the key to the past' (Thornbury, 2002). Therefore in the study, the occurrence of lateral channel migration in the lower section of the river was established. Effects of the migration process on riparian land uses were also established. Gradual increase in anthropogenic encroachment into the channel migration corridor was also observed. The dare need for the delineation of the CMZ for conservation and management measures was also achieved. Consequently, Buffering of the CMZ with possibly a forest wall and establishment of policies will restrict developmental projects within the $\mathrm{CMZ}$ are recommended.

\section{References}

Adebayo, A. A. (Ed). (2004). Mubi region: A Geographic Synthesis. Paraclete Publishers.

Ajala, A. O. and Tammi, H. (2012). Effects of urban sprawl on livelihood of urban fringe in Mubi Adamawa State Nigeria. Challenges of Socio-Economic Development in Nigeria at 50: Issues and policy options. Faculty of Social Science OAU Ile-Ife Nigeria. Waltodany Visual Concepts Lagos. ISSN: 978139906

Alcántara, M. A. S. (2014). Channel Adjustment and Channel-Floodplain Sediment Exchange in the Root River, Southeastern Minnesota. A thesis submitted in partial fulfillment of the requirements for the degree of Master of Science in Watershed Science, Utah State University Logan, Utah.

Boyd, K. P. G., Thatcher, T. and Swindell B. (2010). Ruby River Channel Migration Zone Mapping. Final Report, November 30, 2010; Applied Geomorphology Inc. and DTM Consulting Inc. Pp1-69.

Das, S. and Pal, S. (2016).Character and Cardinality of Channel Migration of Kalindri River, West Bengal, India. International Research journal of Earth Science, 4(1); 13-26.

GeoEngineers (2013). DRAFT Channel Migration Assessment Clallam County. Department of Ecology State of Washington.

Federal Surveys Nigeria, (1970). UBA Sheet 156. Edition 1

Giardino, J. R. and Rowley, T. M.S. (2016). Evaluating channel migration of the lower Guadalupe River: Seguin, Tx, to the San Antonio river confluence. Final Report. Contract No. 1548311790.

Janes, V. J. J., Nicholas, A. P., Collins, A. L., Quine, T. A. (2017). Analysis of fundamental physical factors influencing channel bank erosion: results for contrasting catchments in England and Wales. Environ Earth Sci., 76:307. DOI 10.1007/s12665-017-6593$\mathrm{x}$

King County (2018). Channel migration hazards. Retrieved January 3, 2019 from https://www.kingcounty.gov/services/environment/water-and-land/../migration.aspx

Knighton, D., (1998). Fluvial forms and processes: a new perspective. Arnold, Hodder Headline, PLC.

Larsen, E. W. (2007). Predicting Modes and Magnitude of River Channel Migration and Chute Cutoff Based on Bend Geometry, Sacramento River, California, USA. Technical Report for United States Department of the Interior Bureau of Reclamation Technical Service Center, Denver, CO. Pp 3-5

Legg, N. T. and Olson, P. L. (2014). Channel Migration Processes and Patterns in Western Washington: A Synthesis for Floodplain Management and Restoration. Shorelands and Environmental Assistance Program Report, State Department of Ecology publication.No.14-06-028. https://fortress.wa.gov/ecy/publications/SummaryPages/1406028.html

Leopold, L.B., Wolman, M.G., and Miller, J.P., 1995, Fluvial processes in geomorphology: Courier Dover Publications.

Leopold, L.B., and Wolman, M.G., 1960, River Meanders: Geological Society of America Bulletin, v. 71, p. 769.

Nanson, G. C. and Croke, J. C. (1992). A genetic classification of floodplains: Geomorphology, 4; 459-486

Rapp, C. F. and Abbe, T. B. (2003). A Framework for Delineating Channel Migration Zones. Ecology Final Draft Publication \#03-06027. Retrieved September 7, 2020 from http://www.ecy.wa.gov/biblio/0306027.html

Thornbury, W. D. (2002). Principles of Geomorphology, (2nd Ed.). CNS Publishers and Distributors. Pp 16-17

Wolman, M. G., and Leopold, L. B. (1957). River flood plains: some observations on their formation: US Government Printing Office Geological Survey Professional Paper 282-C, 87-107 p.

Yonnana, E., Dzarma M.S. and Oliver, K. (2020). Assessment of Channel Planform Adjustments in the Mubi Section of River Yedzeram, Adamawa State, Northeastern Nigeria. Jalingo Journal of Social and Management Sciences, 2(3); 176-193 